\title{
Encircling cities from rural areas? Barriers to the diffusion of solar water heaters in China's urban market
}

Zhen $\mathrm{Yu}^{1 *}$, David Gibbs ${ }^{1}$

${ }^{1}$ Geography, School of Environmental Sciences, University of Hull, Hull, UK

\section{Abstract}

Researchers have contributed a fruitful understanding of the facilitating factors for solar water heaters (SWH) diffusion in China at different governance levels. However, the barriers to its further diffusion in the urban environment have so far not been addressed. One feature of SWH diffusion in China is that it emerged from the rural market, mainly driven by market demand. This article explicitly focuses on China's diffusion of SWH from rural areas to urban cities and explores the problems and barriers obstructing its full potential in cities. Applying the Multi-level Perspective (MLP) framework, the results find that the technological niche is still not mature enough, and the urban regime is still powerful in terms of building infrastructure, consumer demand, policy coordination and vested interests. SWH development in China is promoted more as a business opportunity, while environmental discourses have not been powerful enough to promote further diffusion in the urban context. We suggest there is a need to focus on technology innovation with higher industry standards and to implement more benefit-based incentive policies to motivate incumbent actors.

Keywords: Solar water heater, Diffusion of innovation, Multi-level perspective, Urban market. 


\section{Introduction}

Solar thermal energy is a form of technology for harnessing solar energy to generate thermal energy or electrical energy. In 2016, the global installed capacity of solar thermal heat had reached 456 GWth (Weiss et al., 2017) . Besides conventional renewable energies (e.g. hydropower and biomass), the contribution of solar thermal heating in generating green energy is second only to wind power and much higher than solar photovoltaic (PV), but this fact is underestimated in many countries' energy policies (Mauthner and Weiss, 2014). In response to its environmental challenges, China is committed to altering its coal-dominated energy mix by promoting the development of renewable energy. As the world's largest developing economy and largest carbon emitter, China's transition to renewable energy not only addresses its national sustainability concerns, but may also significantly contribute to combating global warming through carbon mitigation and exporting transition experiences. By 2016, China had become one of the world's leading countries in the renewable energy industry with the largest installed capacity in hydropower, wind, photovoltaic (PV) and solar heating globally (REN21, 2017). In particular, China's solar thermal heating accounted for approximately $80 \%$ of global production and $71 \%$ of global installed capacity in 2015 (Weiss et al., 2017). Solar thermal energy has been applied in industry for heating, cooling and drying, but the most common usage of solar thermal energy is for solar water heaters (SWH) in residential and commercial use.

One feature of China's SWH popularisation is that it is mainly driven by market demand for economical sources of hot water, especially from rural areas and small cities (Hu et al., 2012). In addition, with the rising importance of environmental imperatives in China, policy incentives have 
begun to play an important role in promoting SWH in the urban market. In particular, projects which involve SWH-building integration have witnessed a rapid growth in urban markets in the latest decade and China's cities are believed to have leapfrogged over their international counterparts in the application of SWH (Schroeder and Chapman, 2014). Nonetheless, the technology still faces many severe barriers to fulfil its potential in the urban market, especially in large cities.

Previous research, particularly that published in Energy Policy, has contributed a fruitful understanding of the diffusion of SWH in various countries, such as Greece, the UK and Germany (Faiers and Neame, 2006; Mills and Schleich, 2009; Sidiras and Koukios, 2004). These works have mainly been concerned with the drivers and barriers from a user perspective, finding that economic saving is the main driving force and financial cost is the primary barrier. In addition, peer behaviour and environmental awareness also matter in diffusion, although they are not as important as economic factors (Woersdorfer and Kaus, 2011). In the case of China, researchers have explored the facilitating factors of SWH diffusion at the national (Hu et al., 2012), provincial (Goess et al., 2015; Han et al., 2010), and city levels (Li et al., 2011). This work shows that economic saving and convenience are the overarching considerations in adopting $\mathrm{SWH}$, and environmental concern is not viewed as critical (Yuan and Zuo, 2011). Moreover, compared to Israel and Australia for example, the SWH industry in China is seen by local governments more as a business opportunity, rather than a response to energy security or environmental responsibility (Li et al., 2013). While there has been an absence of national incentive policies, some local governments have economic motivations (e.g. employment and fiscal revenue) to support local 
SWH industries through measures such as mandatory installation policies and subsidies.

The existing literature focuses on either user preferences or policies (for an exception, see Goess et al., 2015), which we believe is not sufficient to depict China's SWH development. Other key factors such as infrastructure, institutions, vested interests, and technology on the supply side are overlooked. Given that SWH has been widely adopted in the less wealthy rural market, it is doubtful that financial cost constitutes the main obstacle for SWH diffusion in China's urban market. Instead, we contend that we need a more systematic approach to understand the diffusion covering both production and consumption issues. To this end, the present paper argues that the analysis of SWH diffusion can benefit greatly from sustainability transitions research, which investigates fundamental transformations towards more sustainable modes of production and consumption (Markard et al., 2012). The Multi-level Perspective (MLP) is one of the dominant research frameworks in sustainability transitions research because it provides a straightforward and simplified way to depict complex structural transformations of a system (Smith et al., 2010). The MLP has also been widely applied to purposively promote transitions in desired directions by assessing and diagnosing current ongoing transitions (e.g. Kern, 2012; Liu and Shiroyama, 2013; Nykvist and Nilsson, 2015). The barriers and drivers of transitions identified at the three conceptual levels of the MLP (niche, regime and landscape) allow transition managers to consider the complex factors that are co-evolving and co-determining one another across different scales (Rock et al., 2009).

Another gap we attempt to address is the neglect of spatial difference in SWH diffusion, especially 
from the perspective of rural-urban divisions in China. The rural and urban markets constitute different selection environments for SWH diffusion, but this is under-researched. Conventional diffusion paths suggest that innovations originate in urban markets and then diffuse to rural markets, from central places to the peripheries. By contrast, SWH in China has been mainly popularised in rural areas and small cities, and was only recently encouraged in large cities due to environmental imperatives. In the process this relatively low-tech product is diffusing to a much harder selection environment. Encircling the cities from rural areas is a famous philosophy of revolution by Mao Zedong, which believes armed revolution should start from places where obstructing forces are weak (the rural areas) and then entering harder places (the cities) after power growth in the former place. China's SWH popularisation seems to have followed the same development path, however, the technology has encountered many obstacles on the way from peripheries to the core areas.

Though different cities constitute different selection environments for SWH diffusion (see the contrasting study of SWH diffusion in Dezhou and Beijing, Yu and Gibbs, 2018), this paper aims to explore the general system barriers to the diffusion of SWH in China's urban market. Following this introduction, the next section outlines the SWH industry's development history, policies and problems in China. Section 3 introduces the MLP analysis framework and our research methods. The results are presented and discussed in section 4. Finally, section 5 concludes the paper and provides implications for future research. 


\section{The development contexts and problems of China's SWH industry}

\subsection{Development history}

One feature distinguishing China's SWH industry from other renewable energies is that market demand was the main driving force of its development. Government support played a role in both early and recent years, but it was absent in the interim period. China's central government played a key role in developing the SWH technology before its commercialization in the 1990s (Urban and Geall, 2014). Research on solar thermal technology was continuously supported by the national project of science and technology such as Project $863^{1}$. After entering the civil market, SWH has been developed mainly at the local level without much support from central government. Its industrialisation was largely attributable to the efforts of private entrepreneurs and household consumers (Luo, 2012). Only at the local level were some SWH enterprises listed in the high-tech enterprises' catalogue by local government, and thus enjoyed some favourable policy treatment (Hu et al., 2012). The industry’s development path is divided into three phases:

(1) Start-up phase: 1978-1994. In response to the global oil crisis, China started its research into solar energy by establishing solar research institutions and supporting solar research in top universities at the end of the 1970s. In 1986, Beijing Solar Energy Research Institute imported the Canadian flat-plate copper-aluminum composite production line, which marked the start of China's SWH industry. With the core technology solved, private entrepreneurs began to enter the SWH sector as they realised the potential market demand for hygienic lifestyles and hot water

\footnotetext{
1 Project 863 or China's State High-Tech Research Development Plan was started in March, 1986. It aims to develop advanced technologies in a wide range of fields for the purpose of reducing technology dependence on western countries.
} 
associated with China's rapid economic development. The improvement of flat-plate SWH technology met this demand and dominated China's SWH market in this phase. However, due to the high cost of flat-plate SWH and its low efficiency in winter, as well as the low consumption power of Chinese consumers at that time, the industry grew very slowly (Hu et al., 2012).

(2)The rapid growth of evacuated tube SWH: 1994-2005. In 1994, a technological breakthrough in all-glass evacuated tubes by Tsinghua University, which also developed the corresponding largescale manufacturing equipment, led the industry into a new era. This indigenous technology enabled the mass production of SWH and significantly reduced its cost (Luo et al., 2013). Some leading SWH enterprises initiated massive popularisation of solar energy knowledge around the country. The SWH market quickly expanded in rural areas, facilitated by the rising consumer power of rural residents. Although the initial cost of SWH was higher than electricity water heaters $(\mathrm{EWH})$ and gas water heaters $(\mathrm{GWH})$, it was widely adopted due to the savings on energy bills and the higher price/performance ratio. The following decade witnessed the rapid growth of China's SWH market, with an annual growth rate of 30\% (Wang and Zhai, 2010). During this phase, the evacuated-tube SWH grew to be the dominant SWH, with a market share of more than $90 \%$.

(3) Fast development of SWH-building integration projects: Since 2006. Since the Renewable Energy Law took effect in 2006, many provinces and cities have implemented mandatory installation policies that require new residential buildings to incorporate solar water systems into building design and construction. Accelerated by the rapid growth of the building industry in 
China's urbanisation, the SWH-incorporated building project market (hereafter, project market) experienced a drastic increase, with its market share rising from 35\% in 2007 to $45 \%$ in 2011. The project market is not only confined to residential buildings, but has also rapidly expanded to other buildings such as schools, hotels, hospitals, and factories. By contrast, the individual retail SWH market begun to shrink, especially after 2010. As flat-plate SWHs enjoy advantages in being incorporated into high-rise buildings more conveniently and are more aesthetically attractive, plus reduced cost and improved performance in winter, they experienced a dramatic increase with an annual growth rate of over $50 \%$. Consequently, SWH spread from rural to urban areas, with $25 \%$ of urban households using SWH (Wang and Zhai, 2010).

\subsection{China's policies to promote solar thermal utilisation}

The development of the SWH industry since 2006 owes much to the policy push at the national and local level. In 2005, China's National People's Congress (NPC) promulgated the Renewable Energy Law, prioritising renewable energy generation and utilisation. Regarding solar thermal energy, it states that the government shall encourage the installation of water heating systems and solar heating, and formulate technical and economic policies and technical criteria for the incorporation of solar systems into building construction. In 2007, China's Medium and LongTerm Plan for Renewable Energy (2007-2020) set specific targets for SWH: a total heat collecting area of 150 million square meters to be installed by 2010 and 300 million square meters by 2020 , replacing 30 million tonnes of coal equivalent (TCE) and 60 million TCE respectively. Since then, a series of national and local policies and regulations have been enacted to promote the utilisation of solar thermal energy (Table 1). 
Table 1 The policy environment of China's solar thermal industry

\begin{tabular}{|c|c|}
\hline Law & China's Renewable Energy Law (2006) \\
\hline Plan & $\begin{array}{l}\text { China medium and long-term renewable energy development plan } \\
\text { (2007) } \\
\text { Implementation plan to promote the solar thermal utilisation (2007) }\end{array}$ \\
\hline $\begin{array}{l}\text { National policy } \\
\text { documents }\end{array}$ & $\begin{array}{l}\text { Notice to accelerate the popularisation and application of solar water } \\
\text { heating systems (2007) } \\
\text { Energy saving regulations for civil constructions (2008) } \\
\text { Notice to further promote renewable energy construction application } \\
\text { (2011) }\end{array}$ \\
\hline $\begin{array}{l}\text { Support } \\
\text { measures }\end{array}$ & $\begin{array}{l}\text { Special funds } \\
\text { Subsidy } \\
\text { Industry standards } \\
\text { Demonstration projects }\end{array}$ \\
\hline $\begin{array}{l}\text { Local incentive } \\
\text { policies }\end{array}$ & $\begin{array}{l}\text { Mandatory installation policy } \\
\text { Subsidies } \\
\text { High-tech enterprise }\end{array}$ \\
\hline
\end{tabular}

The most influential policies are the Household Appliance Going to Countryside by the Ministry of Finance and Ministry of Commerce, and the mandatory installation policy at the local level. Between 2008 and 2013, the Household Appliance Going to Countryside policy provided subsidies (13\% of the product price) for rural residents to purchase new home appliances or to trade-in old appliances for new ones. SWH is listed in the subsidy catalogue, with a ceiling of RMB5000 (US\$ 750) per SWH. Some local governments provide extra subsidies for purchasing SWH, reducing its initial capital cost by up to two-thirds of the price (Li et al., 2011). In urban markets, since 2007, 20 provinces and 80 municipal governments have issued a mandatory installation policy (Huo and Luo, 2012), requiring new residential buildings to integrate SWH. Most local governments require that buildings of, or less than, 12 stories should install SWH. 
Those projects that are not in accordance with the requirement will not be given permission for construction or completion inspection. These policies and regulations have given a powerful push to the diffusion of SWH in both rural and urban markets.

\subsection{Problems of SWH in entering urban markets}

However, the industry still faces many severe problems in entering urban markets. On the supply side, China's SWH industry has been criticised for its weak technological innovation. After the breakthrough of evacuated tube technology, the subsequent two decades have not seen any radical innovations in the industry. In addition, the dominant evacuated tube SWHs in China are problematic to fully integrate with high-rise buildings. Evacuated tube SWHs are currently popular in rural areas and small and medium-sized cities, but are unable to cater to the high-end demand in large cities (Hu et al., 2012). As for flat-plate collectors, China's SWH enterprises have made certain improvements such as solving the problem of freezing in winter. However, the core technology of solar thermal absorption film is still beyond the capacity of China's SWH enterprises. The cost of flat-plate collectors remains high because Chinese enterprises have to pay to import the core technology from foreign countries. Among the 3000 SWH enterprises in China, only around 20 of them have large-scale production and R\&D capacities (GTMS, 2012). The products on the market are limited in the product category and very homogenised (Hu et al., 2012).

On the demand side, such weak innovation brings about vicious market competition. As the SWH products are very homogenous, most enterprises choose to differentiate their products from others by lowering prices. Consequently, the product quality is not guaranteed. Many enterprises sell 
poor quality SWH at low prices, which not only drives out good quality SWH enterprises, but also renders a bad reputation of China's SWH industry to consumers. In project markets, estate developers in many cities have to install SWH under the mandatory requirement, but they do not trust the performance of SWH. As a result, they tend to install inferior SWH systems to minimise the costs of what they believe are unreliable systems. The fact that low price wins projects further aggravates the vicious competition of SWH enterprises and distracts the SWH industry from technological innovation. Some cities have cancelled the mandatory installation policy due to poor inspection and quality control issues. The remainder of this paper explores the systemic roots of these problems.

\section{Methodology}

\subsection{Research framework}

The MLP conceptualises transitions as shifts from one socio-technical system to a new one through the interaction of processes at three levels: landscape, regime, and niche (Geels 2002). The three levels refer to different degrees of stability, with niche being the most dynamic and landscape the most stable (Geels, 2011). The regime is the key concept in socio-technical transitions, defined as a "semi-coherent set of rules that orient and coordinate the activities of the social groups that reproduce the various elements of socio-technical systems" (Geels, 2011:27). A regime is characterised by path dependence and lock-in as a result of "a logic and direction for incremental socio-technical change along established pathways of development" (Markard et al., 2012:957). These pathways occur in the interaction of sub-regimes, such as technology, culture, policy, markets, science etc., which have their own dynamics and co-evolve with each other. 
Regimes contain coherences, shared values, and similarities on the one hand, but also varieties, disagreements, debates, and internal conflicts on the other hand (Geels, 2011). Verbong and Geels (2010) identify three dimensions of socio-technical regimes: a) material and technical elements (e.g. resources and infrastructures); b) networks of actors and social groups (e.g. producers, industrial users, and households); and c) formal, normative and cognitive rules (e.g. regulations, belief systems, guiding principles and behaviour norms). Nonetheless, it is not necessary that these dimensions would invariably be reflected in different socio-technical regimes. In practice, regime resistance can be performed in different forms and to different extents.

A niche is a 'protected space' where radical innovations emerge for path-breaking from the incumbent regime (Rip and Kemp, 1998). Niches function as incubators, such as R\&D laboratories, specific market segments, and demonstration projects, protecting new technologies from the selection pressure of existing systems. This shielding function of a niche can be achieved through either providing passive space, i.e. generic space pre-existing deliberate mobilisation, or creating active space, i.e. deliberately created space where selection pressures are held off (Smith and Raven, 2012). There are three key processes in niche development: a) articulation of expectations and visions; b) social networking of heterogeneous actors; and c) social learning and articulation process (Geels and Raven, 2006; Kemp et al., 1998). Through these processes, niche innovations may develop enough momentum to challenge the established regimes. Therefore, niches are the seeds for the transition by possessing the potential to substitute current technologies, alter user practices and change institutional structures, leading to a new regime. However, such change is not inevitable and niches may fail to gain traction. 
The landscape is the collection of external factors which affect the dynamics of niches and regimes, but are unlikely to be influenced in reverse in the short run (Rip and Kemp, 1998). A socio-technical transition happens when a) landscape changes bring pressure to bear on regimes and provide legitimacy to niche activities; b) regime destabilisation occurs as internal conflicts emerge, creating windows of opportunities for niche innovations; and c) niche innovations gain momentum to challenge and replace the regime through articulating expectations, social learning, and mobilising heterogeneous actors (Geels, 2011). The MLP is believed to be a robust framework in delineating sustainability transitions due to its ability to order and simplify the analysis of complex structural transformation (Smith et al., 2010).

Regarding China's SWH diffusion, we believe that the general landscape of global and national concerns over carbon emissions and environmental degradation, as well as national low-carbon development and policy changes have exerted increasing pressures on incumbent energy regimes in China, but these are still not imperative enough to force deeper changes in incumbent regimes. The main barriers, we hypothesise, lie in the struggle between weak niche innovations and strong regime resistance. As Boschma et al., (2017) argue, there is variance in the extent to which a regime is regionally institutionalised and transitions are less likely to occur in those regions where a regime is strongly aligned with local institutions, the knowledge base, and vested interests. The rural market was a niche space of China's SWH development in its early days. Since the landscape of green development has become increasingly imperative within China, the niche development has gained more momentum to enter the urban market, but here the regime is much more hostile to 
SWH diffusion. The incumbent infrastructure, market demand, and vested interests in urban areas pose hard obstacles for this niche innovation.

\subsection{Method}

We adopted a mixed-methods approach because it allows the researcher to undertake

'triangulation', that is, employing various data sources and collection procedures to study the same phenomena (Hoggart et al., 2002). Interviews formed the primary data source of the research on which this paper is based. During fieldwork in China from November 2014 to March 2015, 36 semi-structured interviews were conducted with solar enterprise respondents, government officials, research institutes and estate developers, mostly in Shandong and Beijing, which are the two main SWH clusters in China. Questions in the interviews covered the themes of SWH technology, market development, government policy, actor activities, and other driving and obstructing forces of SWH diffusion. The interviews also explored respondents' experiences in the industry, as well as how decisions were made and how these decisions influenced SWH development. In addition, document analysis, site observations, and attendance at industrial conferences were used as supplementary data collection methods for triangulation. The documentary materials include laws, governmental policies, statistical data, newspapers, industrial and scientific studies, and market reports. Site observations helped us gain a direct understanding of technical artefacts, infrastructure, and user practices. By attending the Annual Conference of China's Solar Thermal Industry (2014), we gained an overview of both the status quo and problems facing the industry, as well as observing the interaction and relationship between various actors. Data from these materials were coded and aggregated to themes under the three categories of landscape pressure, niche development and regime resistance. 


\section{Results and discussions}

\subsection{Insufficient landscape pressure}

The general landscape of low-carbon development, especially after the Renewable Energy Law was enacted, has given a strong push to the development of China's SWH with policy support from the national and local levels. However, this landscape of green discourse at the global and national level is not always interpreted as being imperative at the local level. As Li et al., (2013) argued, the SWH industry in China is predominantly supported from an economic rationale at the local level, rather than on the basis of environmental discourses. Compared to PV, solar thermal energy has received much less policy support from both national and local governments. On the one hand, this might be due to the assumption that solar thermal technology is already advanced enough and the technology has been widely commercialised (Urban and Geall, 2014). On the other hand, there is a strong preference among governments for those renewable energies that generate electricity rather than producing heat (interviews 10, 11, 32). Electricity is regarded as an indispensable for a society, while heat is not essential. Furthermore, at the local level, the preference for PV or wind energy has much to do with China's cadre performance evaluation system (CPES), in which those government officers performing well in economic development terms have more opportunities for promotion. Although the CPES has been reformed in recent years to incorporate more social and environmental criteria, it remains a GDP-orientated system in many places at the local level. The PV and wind industry seemingly brings more investment and thus GDP. In 2014, China's overall output of SWH industry was less than RMB 100 billion (US\$ 15 billion), while the annual output of PV exceeded RMB 500 billion (US\$ 75 billion). Logically, local governments therefore have more motivation to support the PV 
industry (interview 30). Moreover, solar thermal energy is generally deemed a low-tech technology (Schroeder, 2010), which is not consistent with many local governments' visions to pursue high-end and high-tech industry (interview 12). This political landscape weakens government support for the SWH industry, which generally has a limited role to play in local economies. Except for a few cases such as in Dezhou (Li et al., 2011; Yu and Gibbs, 2018), the SWH industry has had little success in lobbying for favourable policy support from local governments.

Except for the mandatory installation policy, SWH industry often seems a free rider on other renewable energy policies or even policies for other industries, and has seldom been the main policy object. Taking the Household Appliance Going to Countryside Policy as an example, it is not designed for promoting the utilisation of SWH, but for expanding domestic markets for the household appliance industry, which suffered from a huge shrinking export market caused by the global financial crisis in 2008. SWH was just one of the products listed in the appliance catalogue going to the countryside, which also includes conventional water heaters. Though the SWH industry does benefit from this policy, it does not gain any favourable advantages over conventional water heaters. Therefore, the landscape is still not pressing enough to promote this grass-roots environmental technology into urban regimes.

\subsection{Weak niche development}

Niche development usually consists of technology development, actor activities and networks.

Three themes emerged from the data: technology imperfection, policy reliance, and restrictions on large SWH enterprises, implying a weak niche development. 


\subsubsection{Technological imperfection}

The technological performance of the innovation itself is an important determinant of its diffusion.

China's SWH technology has made many significant breakthroughs in reducing cost and

improving performance, but the technology is still confronted with many problems in performance such as unreliability, safety, aesthetic concerns and system design. The technology has long been deemed as a low-end product by many urban residents and municipal managements, which is related to the weak innovation capacity of the industry. This is attributed substantially both to the lack of available high-skilled talent (Goess et al., 2015) and weak system design capacity within the industry.

Before 2005, the SWH industry had been known as a peasant industry. Except for a few entrepreneurs in large enterprises, many entrepreneurs in the industry were previously farmers without higher education backgrounds. Most of them initially entered the SWH industry as local sales agents for large SWH enterprises (interviews 12,33) and then started their own firms because they found the industry highly profitable and because SWH technology was not difficult to imitate. More than $60 \%$ of the SWH market was dominated by small firms, many of which were family workshops. Most of these small firms are speculative and sell SWH locally. These entrepreneurs barely invested in technology development and have been focused on market creation, while neglecting investment in human resources and R\&D.

SWH is a comprehensive technology involving the synergy of many different disciplines. In China's higher education system, there is no specific academic major on solar water systems. In 
the case of SWH-building integration, this involves building design institutes, estate developers and SWH suppliers, but the architects do not have much knowledge about solar water systems, while the SWH suppliers lack knowledge of building design. Although there have been cooperative efforts between SWH enterprises and universities to train talent for SWH-building incorporation, numbers are still in short supply (interview 16).

The performance of SWH-building integration depends much more on the quality of system design, rather than on individual SWH products. The efficiency of solar collectors is only a part of the system performance, while thermal energy storage and transportation to end users are also critical to the eventual performance. In addition, due to the unreliability of solar energy, many SWH-building integration projects choose to add a supplementary energy supply system, usually electricity or gas. The supplementary system works when the solar thermal system ceases working during the night or in unfavourable weather. However, in practice, having two systems not only increases users' initial installation costs, but also represents a huge challenge to system design. Poor system design causes more energy waste and higher energy bills. For instance, a lot of electricity or gas could be consumed to boil the large volume of water in a water tank repeatedly in order to keep its working temperature if the solar system ceases working for a long time (interview 30). Moreover, due to the limited supply of specialised talent in SWH-building integration, neither building design institutions nor SWH firms can maximise the system efficiency by themselves. Sometimes, in order to keep the aesthetic appearance of buildings, architects would rather sacrifice the efficiency of the solar system (interviews 33, 36). As every building differs from each other, the system design of each SWH-building integration project also 
varies. So far, a standard system performance has not been guaranteed due to the weak system design of SWH-building projects.

\section{2.2 Policy reliance}

After 2012, China's SWH retail market experienced a sharp decrease. The Household Appliance

Going to Countryside Policy is widely believed within the SWH industry to be responsible for the downturn. Although the industry witnessed the fastest growth during the application of the policy between 2009 and 2012, it has been criticised for affecting future markets. As one interviewee said:

the policy stimulates the market suddenly, meeting its long-term demand in a short period of time. It's like the sales promotion in the supermarket, the first three days is ok, but the fourth day will see a steep decrease in the sale when the promotion cease [interviewee 35].

The reliance on policy incentives is also responsible for the lack of technology innovation (Goess et al., 2015), as one entrepreneur commented:

The majority of SWH firms merely took advantage of the incentive policies ... they did not invest in $R \& D$ talents and technology innovation for urban project markets, not even management equipment [interviewee 12].

At the peak of the industry, there were around 5000 SWH enterprises in the market when the policy was operational. As the policy ceased, a large number of small local SWH enterprises ceased to operate. Many enterprises grew quickly in terms of sales due to the policy, but they did not engage in developing product quality or technology research. The policy is also responsible for poor SWH-building integration after 2012. Too much focus was given to competing in the 
rural retail market and very few enterprises committed to upgrading technologies for urban project markets. When the policy ended and urban project markets began to grow, most of the SWH enterprises lacked the talent and technology capacity needed to successfully engage in SWHbuilding integration projects.

\title{
4.2.3 Restrictions on large SWH enterprises
}

Though a number of large SWH enterprises have developed the technological capacity for SWHbuilding integration, they are restricted from competing in the project market. One characteristic which differentiates project markets from the retail market is that 'guanxi' or personal relationships are an important factor determining whether an SWH firm can win project bids. In the retail market, individual consumers choose SWH products based on price, quality and reputation, where large SWH enterprises have more influence. Conversely in the project market, local SWH enterprises normally have a closer interpersonal relationship with local estate developers and government projects, which makes it difficult for large non-local SWH enterprises to enter the market. Though many large estate developers focus more on SWH quality, guanxi is still an underlying consideration in decision making (interviews 1,4,5,12,14,30). When asked what his enterprise mostly needed, one interviewee answered:

\author{
Guanxi or connections, that's how the project market runs. Be it estate \\ developers or government projects, it is difficult to win the bids without \\ interpersonal connections. Given the similar products and prices, surely they \\ will give the offers to someone they have already known [interviewee 2]
}

Another barrier that restrains large SWH enterprises in project markets is their financial capacity. The SWH project market is highly dependent on real estate markets, while estate developers, in 
most of the cases, only see SWH integration as a mandatory burden. Consequently, the SWH industry lacks negotiating power with the estate industry. Most estate projects require SWH enterprises to cover the upfront investment of SWH-building integration and they are only paid after completion, which is often not guaranteed. SWH enterprises face financial strain due to the long pay-back time of project funds, and thus are not able to construct many SWH-building projects at the same time. Even worse, estate developers may refuse to pay back the upfront cost. As one interviewee put it:

\author{
even if you have the guanxi, you may not able to afford the upfront \\ investment... how many connections can you have around the country? It is \\ difficult for an SWH enterprise to become bigger in project market. It requires \\ a lot of financial investment. Many estate developers break their faith with \\ SWH enterprises and you don't get your money back [interviewee 30].
}

\title{
4.3 Strong regime resistance
}

When this grass-roots technology was encouraged to enter the urban project market, strong regime

resistance has stood in the way in terms of building infrastructure, market demand, government

intervention and conflicts of interest among actors.

\subsubsection{Incompatible building Infrastructure}

Mills and Schleich (2009) find that residential characteristics, including the age of the residence and layout affect the adoption rate of SWH in Germany. Generally, the older and the higher a residential house is, the less likely it is to install a solar system. This also applies in the Chinese context. The high residential buildings that have sprung up in China's cities constitute a part of the hard selection environment for SWH diffusion. Unprecedented urbanisation in China means 
enormous physical landscape changes in building infrastructure to accommodate its growing population and economic activities. Since the 1980s, China's large cities started building tower buildings on a large scale, to reduce land use and provide more residential housing apartments, resulting in high intensity land use. Many Chinese large cities no longer approve low-rise residential buildings in their urban areas. Urbanisation, in the physical term, is therefore a 'lockedin' process, narrowing the options for new innovations. The rigid urban building infrastructure not only imposes a direct obstacle to the integration of $\mathrm{SWH}$, but more importantly, it is also the logical base for many social practices, mindsets and policy making.

\subsubsection{Distorted market demand}

Market demand is perhaps the most challenging selection environment for new innovations. An innovation is adopted not simply because of its relative advantages in various forms, but also depends on how these relative advantages are perceived by potential adopters and whether they fit their needs. In the rural market, SWH consumers tend to care more about cost rather than quality. Under the Household Appliance Going to Countryside policy, rural markets were filled with inferior products by small SWH enterprises due to low industry standards (interviews 1,4,12, 18). This had a severely negative influence on the growth of SWH industry in urban markets as consumers no longer trusted SWH performance. Even though SWH provides advantages in economic savings, the relatively wealthy urban consumers are more concerned about the negative side of the technology. Compared to their rural counterparts, urban consumers generally have more demands for convenience, safety, aesthetics and even social status, which is very difficult for grass-roots SWH technology to meet. Instead, EWHs and GWHs have gained much more popularity in urban markets which poses a considerable challenge for SWH to replace them. 
Higher incomes in urban areas also means that residents are less concerned with energy bills, which renders renewable energy options less attractive (interview 32).

For project markets, estate developers have a different rationale. Reducing building cost is the priority for most estate developers. Under the mandatory installation policy, estate developers strive to decrease SWH installation costs as much as possible. As a consequence, the majority of estate developers choose to install low price solar water systems, regardless of the quality (interviews 1,28). The mandatory policy only requires new buildings to install SWH systems, but with no specific requirements on eventual system performance. The inspection of mandatory installation merely checks whether estate developers have installed a solar water system, but little attention is paid to how well the system works. Some estate developers even remove the solar water system from buildings after the inspections (interview 12). In response, SWH suppliers are forced to reduce the cost of their products in order to win bids to estate developers. Without enough quality control, the price battle only leads to inferior products, which in turn destroys the profile of the whole industry, forming a vicious circle. As one SWH manufacturer stated:

Estate developers only view it as a mandatory quota to comply with the policy, if you don't install SWH, you can't get through inspection. They are not doing this seriously, all they want is to deal with the inspection [interviewee $33]$.

\subsubsection{Inappropriate government intervention}

Ineffective innovations may be diffused through a decentralised system because of a lack of quality control (Rogers, 2003). China has around 30 relevant industry standard policies on SWH, 
but most of these are local level policies and are not strictly implemented. The industry entry barrier is low due to the poor implementation of industry standards. Another cause of the poor implementation of industry standards is that it is difficult to inspect the performance of SWH projects. So far, there are only three quality test centres for SWH in China. For SWH-building integration projects in particular, it is difficult and costly to test the performance of the entire system, which can perform differently according to weather and building conditions. Specialised inspection teams have not been established and the performance standards of SWH-building integration that should have been complied with are missing (interview 32).

Thus while most interviewees from SWH industries cited the positive effect that the mandatory installation policy brings about, they also complained about its poor implementation (interviews 1, $2,5,12,29,31)$. The mandatory installation policy is issued by many local governments in the form of implementation opinions or administration measures, which only have limited legal force, and thus the violation of this policy is not necessarily punished. During China's urbanisation, the real estate industry has played an increasingly important role in the local economy and municipal finance revenue. Many cities' finance systems are dominated by land finance, that is, a large share of municipal revenue comes from land development (Lin and Yi, 2013). By contrast, the role of SWH industry in the local economy is often so small that it can be ignored and many cities do not implement the mandatory installation policy stringently in order to protect their revenue from the real estate industry (interview 12). Local protectionism is also believed to be responsible for the poor implementation of industry standards (Luo et al., 2013). In those cities where the SWH industry does play a bigger role in the local economy, inspection of SWH products and projects is 
often not strictly implemented, in order to protect the local SWH industry.

The institutional cause of poor implementation owes much to government's conflicting role between marketisation and regulation (interviews 30, 32). In China's current market environment where trust is absent, inferior products would destroy market order without quality control regulation, thus, complete marketisation is deemed impossible. Market failure and concerns to maximise SWH's positive environmental externalities call for proper government intervention. On the government side, it is difficult to decide the proper extent and form of intervention. Too much intervention with strict industry standards may hinder market competition and lead to monopoly and corruption. To make matters worse, the government does not have enough capacity and resources to supervise properly. The current third-party inspection institution is China's Solar Thermal Industry Association (CSTIA), which is actually a quasi-government institution. In China, industry associations used to be affiliated with corresponding government departments and the CSTIA was under the Ministry of Agriculture. This government background makes the CSTIA less independent and unable to monitor the industry from an unbiased standpoint (interview 30).

\subsubsection{A trilemma among actors}

The poor implementation of SWH-building integration is attributed to the trilemma among architecture design institutes, SWH enterprises, real estate developers and governments. Architecture design institutes are generally not interested in SWH integration, nor do they have much knowledge about the solar water systems. Some architectural design institutes even delegate their design responsibility to SWH firms. A senior architect explained a part of the story: 
its difficulty and contents have been increased a lot. Architects ... do not want

to spend more energy on new things like SWH. Instead, they pass the design responsibility to SWH enterprises and approve their design [interviewee 28].

Table 2 The interests, capacities and actions of main actors

\begin{tabular}{|c|c|c|c|}
\hline Actors & Interests & Capacity & Actions \\
\hline $\begin{array}{l}\text { Central } \\
\text { government }\end{array}$ & $\begin{array}{l}\text { Green economy, carbon } \\
\text { mitigation, environment } \\
\text { improvement }\end{array}$ & $\begin{array}{l}\text { Lack of supervision } \\
\text { capacity at local } \\
\text { level }\end{array}$ & $\begin{array}{l}\text { Renewable Energy Law, } \\
\text { Encouraging SWH } \\
\text { installation policies, } \\
\text { Demonstration cities }\end{array}$ \\
\hline $\begin{array}{l}\text { Local } \\
\text { governments }\end{array}$ & $\begin{array}{l}\text { GDP, tax revenue and } \\
\text { employment, meeting } \\
\text { Central government green } \\
\text { targets }\end{array}$ & $\begin{array}{l}\text { Lack of inspection } \\
\text { resources and } \\
\text { capacity }\end{array}$ & $\begin{array}{l}\text { Mandatory installation; } \\
\text { But loose implementation } \\
\text { and inspection of industry } \\
\text { standard }\end{array}$ \\
\hline $\begin{array}{l}\text { Architect design } \\
\text { institutions }\end{array}$ & $\begin{array}{l}\text { Design revenue, not } \\
\text { interested in } \mathrm{SWH}- \\
\text { building design, reducing } \\
\text { design duties }\end{array}$ & $\begin{array}{l}\text { Lack of } S W H- \\
\text { building design } \\
\text { capacity }\end{array}$ & $\begin{array}{l}\text { Poor system design; } \\
\text { Passing design to } \mathrm{SWH} \\
\text { firms }\end{array}$ \\
\hline $\begin{array}{l}\text { SWH } \\
\text { enterprises }\end{array}$ & $\begin{array}{l}\text { Winning project bids, } \\
\text { reducing product cost }\end{array}$ & $\begin{array}{l}\text { Weak system design } \\
\text { capacity }\end{array}$ & $\begin{array}{l}\text { Dependent on low price } \\
\text { and guanxi rather than } \\
\text { technology capacity to win } \\
\text { bids; or providing inferior } \\
\text { products }\end{array}$ \\
\hline $\begin{array}{l}\text { Estate } \\
\text { developers }\end{array}$ & $\begin{array}{l}\text { Getting through } \\
\text { mandatory inspection; } \\
\text { reducing installation cost }\end{array}$ & $\begin{array}{l}\text { Unable to } \\
\text { implement SWH- } \\
\text { building design }\end{array}$ & $\begin{array}{l}\text { Using inferior SWH; } \\
\text { Removing SWH after } \\
\text { inspections }\end{array}$ \\
\hline
\end{tabular}

As illustrated in Table 2, there are many conflicts of interest between governments, SWH

suppliers, architectural design institutes and estate developers. Though the national discourse

advocated by the central government is to develop a green economy and reduce carbon emissions, the priority for local governments is still economic development in most cases. Moreover, for the 
design institutes, estate developers, and SWH enterprises, reducing cost is an inherent part of their decision-making process, as profit-seeking organisations. In spite of many local governments issuing mandatory policies to meet the green economy discourse, the capacity failure in implementation and supervision provides room for business actors to escape the regulations. Another problem is that many government bureaus are involved in the inspection, making it unclear what their respective responsibilities are, not to mention the conflict of interests involved (interview 11). The weak system design capacity of business actors further leads to actions that are against the initial objective of the policy. Hence, the bottlenecks of SWH-building integration lies not only in technological development, but also in the lack of an incentive mechanism to motivate relevant actors, especially the estate developers (Li et al., 2007).

\section{Conclusions and implications}

This paper has provided a systemic analysis of SWH diffusion from a rural-urban spatial perspective. The same innovation can have very different purchase in different places, depending on how the local selection environment reacts to it. It is logical that a new innovation could face more obstacles in those places with a more demanding environment because their immature nature could often be amplified. Despite Chinese global leadership in the diffusion of SWH, it is confronted with many systematic barriers to further popularisation in China's urban market. Drawing insights from the MLP framework, we find that the less successful SWH diffusion in China's urban market is a combined result of the interaction between insufficient landscape pressure, strong regime resistance, and weak niche developments (Figure 1). 


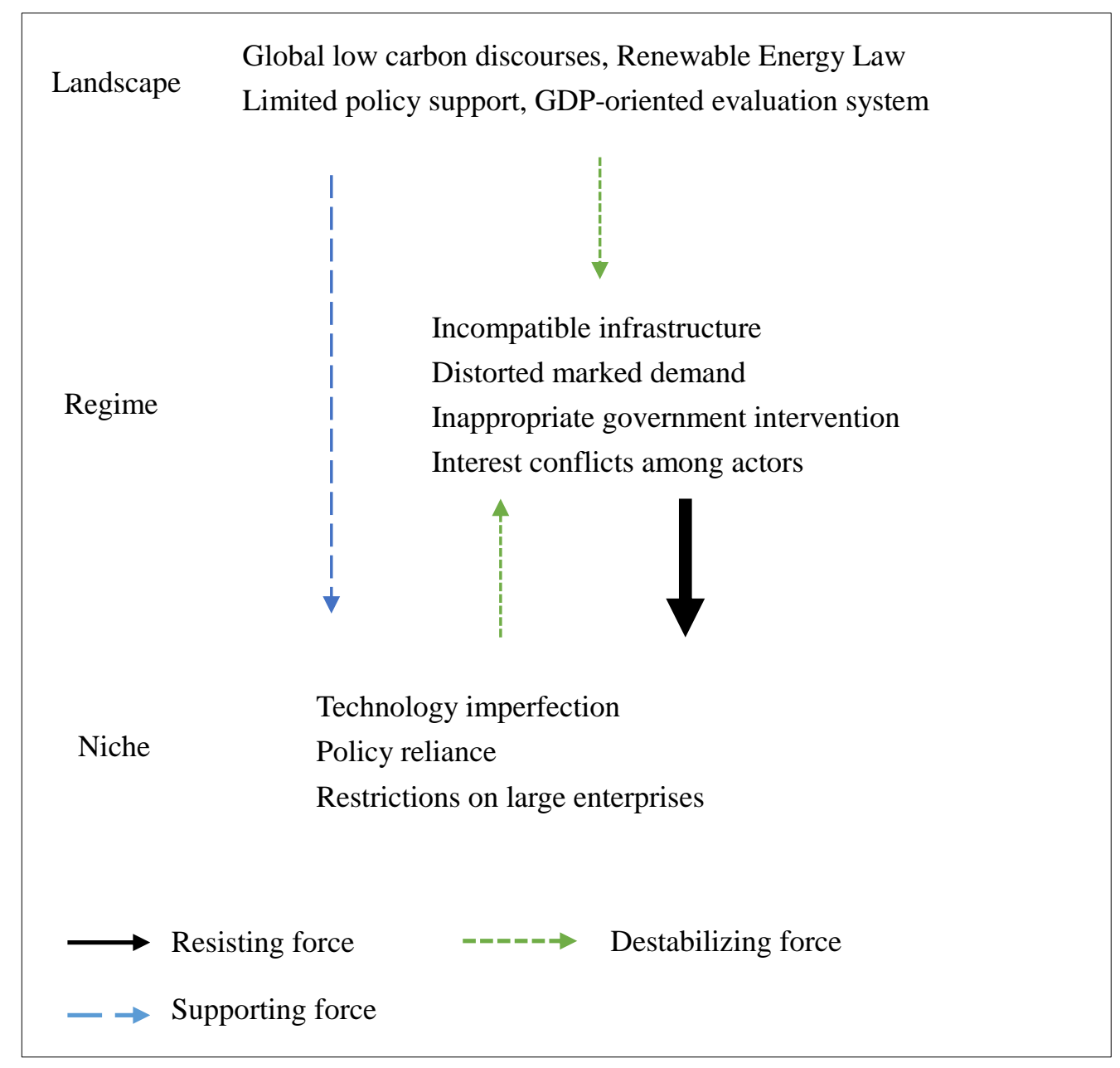

Figure 1 The multi-level interaction of the SWH diffusion in China's urban market

The general landscape of international concerns over carbon emissions and national Chinese policies for green development has formed a favourable context for SWH diffusion in terms of legal institutional changes and renewable energy discourses, but it is still not forceful enough to exert more pressure on incumbent regimes. China's fast economic growth has been a strong market pull for SWH diffusion, but its political landscape has provided much less incentive for governments to invest in this grass-root technology. Since the industry is mainly driven by an economic rationale, environmental discourses are not an adequate imperative to encourage further diffusion in the urban market. Moreover, the technology is still not advanced enough to meet the 
high-end demands of urban markets. Economic savings have not provided enough incentive for urban consumers to adopt SWH. In addition, shortages of skilled-talent, weak system design, and price-oriented demand undermine the industry's innovation capacity. As the industry has only a small role in economic development, it unable to lobby for strong policy support. In terms of regime resistance, the building infrastructure, high-end market demand, absent role of government, and conflicts of interest among actors, constitute a very selective environment for the SWH to grow in urban space. Lack of high industry standards and poor quality inspection further aggravates the market environment, making it difficult for good innovations to develop. While the rural market seems to have provided an 'empty' space for the technology, the urban market is apparently an 'occupied' space with many vested interests, which is shaped by China's economic, political and cultural landscape. Without institutional forms to provide incentives and a strict quality inspection institution, environmental regulation could simply lead incumbent actors to evade their obligations with least cost, resulting in an opposite effect.

Instead of focusing on the shielding and nurturing processes of innovations in specific niche spaces, this paper mainly contributes to the MLP literature by investigating the barriers to scaling up a grass-roots niche innovation to a more demanding selection environment in China's urban context. Most MLP studies have advocated lower entry barriers to provide 'incubation room' for niche innovations at the initial stage. However, when it comes to expanding to a harsher environment, a guarantee of technology performance at a certain standard is needed. Furthermore, the MLP literature has mainly focused on high-tech innovations, but the comparatively cheaper but 'good enough' low-tech innovations are also of global significance in sustainability transitions 
(Tyfield and Jin, 2010). Future research could reap more benefits from studying these 'disruptive innovations' (Christensen, 1997) in the context of developing countries because they possess considerable potential to move up markets and eventually emerge as dominant, though many system barriers are expected before they realise their full potential.

\section{Acknowledgement}

Thanks are due to all the interviewees in China who gave up their time for interviews. 


\section{References}

Boschma, R., Coenen, L., Frenken, K., Truffer, B., 2017. Towards a theory of regional diversification: combining insights from evolutionary economic geography and transition studies. Reg. Stud. 51, 31-45. doi:10.1080/00343404.2016.1258460

Christensen, C.M., 1997. The innovator's Dilemma, Business. doi:10.1515/9783110215519.82

Faiers, A., Neame, C., 2006. Consumer attitudes towards domestic solar power systems. Energy Policy 34, 1797-1806.

Geels, F., Raven, R., 2006. Non-linearity and expectations in niche-development trajectories: ups and downs in Dutch biogas development (1973-2003). Technol. Anal. Strateg. Manag. 18, 375-392.

Geels, F.W., 2011. The multi-level perspective on sustainability transitions: responses to seven criticisms. Environ. Innov. Soc. Transit 1, 24-40. doi:10.1016/j.eist.2011.02.002

Geels, F.W., 2002. Technological transitions as evolutionary reconfiguration processes: a multi-level perspective and a case-study. Res. Policy 31, 1257-1274. doi:10.1016/S0048-7333(02)00062-8

Goess, S., de Jong, M., Ravesteijn, W., 2015. What makes renewable energy successful in China? The case of the Shandong province solar water heater innovation system. Energy Policy 86, 684-696. doi:10.1016/j.enpol.2015.08.018

GTMS, 2012. Solar Water Heater Market Report.

Han, J., Mol, A.P.J.J., Lu, Y., 2010. Solar water heaters in China: a new day dawning. Energy Policy 38, 383-391. doi:10.1016/j.enpol.2009.09.029

Hoggart, K., Lees, L., Davies, A., 2002, Researching human geography, Arnold, Lond.

Hu, R., Sun, P., Wang, Z., Runqing, H., Peijun, S., Zhongying, W., 2012. An overview of the development of solar water heater industry in China. Energy Policy 51, 46-51. 
doi:10.1016/j.enpol.2012.03.081

Huo, Z., Luo, Z., 2012. Annual report of China's solar thermal industry development. Sol. Energy (in Chinese) 6-11.

Kemp, R., Schot, J., Hoogma, R., 1998. Regime shifts to sustainability through processes of niche formation: the approach of strategic niche management. Technol. Anal. Strateg. Manag. 10, 175195.

Kern, F., 2012. Using the multi-level perspective on socio-technical transitions to assess innovation policy. Technol. Forecast. Soc. Change 79, 298-310. doi:10.1016/j.techfore.2011.07.004

Li, W., Rubin, T.H., Onyina, P. a., 2013. Comparing Solar Water Heater Popularization Policies in China, Israel and Australia: The Roles of Governments in Adopting Green Innovations. Sustain. Dev. 21, 160-170. doi:10.1002/sd.1547

Li, W., Song, G., Beresford, M., Ma, B., 2011. China's transition to green energy systems: The economics of home solar water heaters and their popularization in Dezhou city. Energy Policy 39, 5909-5919. doi:10.1016/j.enpol.2011.06.044

Li, Z., Zhang, G., Li, D., Zhou, J., Li, L., Li, L., 2007. Application and development of solar energy in building industry and its prospects in China. Energy Policy 35, 4121-4127. doi:10.1016/j.enpol.2007.02.006

Lin, G.C.S., Yi, F., 2013. Urbanization of Capital or Capitalization on Urban Land? Land Development and Local Public Finance in Urbanizing China. Urban Geogr. 32, 50-79. doi:10.2747/02723638.32 .1 .50

Liu, D., Shiroyama, H., 2013. Development of photovoltaic power generation in China: A transition perspective. Renew. Sustain. Energy Rev. 25, 782-792. 
Luo, Z., 2012. The development of solar thermal utilization industry: retrospect and prospect. Constr. Technol. 22-25.

Luo, Z., Huo, Z., Xie, G., 2013. The report of China's solar thermal industry development(2011-2012). Sol. Energy (in Chinese) 7-10.

Markard, J., Raven, R., Truffer, B., 2012. Sustainability transitions: An emerging field of research and its prospects. Res. Policy 41, 955-967. doi:10.1016/j.respol.2012.02.013

Mauthner, F., Weiss, W., 2014. Solar Heat Worldwide: markets and contribution to the energy supply, IEA SHC. Graz. doi:10.1017/CBO9781107415324.004

Mills, B.F., Schleich, J., 2009. Profits or preferences? Assessing the adoption of residential solar thermal technologies. Energy Policy 37, 4145-4154. doi:10.1016/j.enpol.2009.05.014

Nykvist, B., Nilsson, M., 2015. The EV paradox - A multilevel study of why Stockholm is not a leader in electric vehicles. Environ. Innov. Soc. Transit 14, 26-44. doi:10.1016/j.eist.2014.06.003

REN21, 2017. Renewables 2016: Global Status Report.

Rip, A., Kemp, R.P.M., 1998. Technological change. Battelle Press.

Rock, M., Murphy, J.T., Rasiah, R., van Seters, P., Managi, S., 2009. A hard slog, not a leap frog: Globalization and sustainability transitions in developing Asia. Technol. Forecast. Soc. Change 76, 241-254. doi:10.1016/j.techfore.2007.11.014

Rogers, E.M., 2003. Diffusion of Innovations, 5th ed. Free Press, New York

Schroeder, P., 2010. Leapfrogging in China's Renewable Electricity Development Pathway? The Roles of Policy Frameworks, Innovation and International Cooperation Partnerships in fostering renewable electricity. Victoria University of Wellington. Wellinton.

Schroeder, P.M., Chapman, R.B., 2014. Renewable energy leapfrogging in China's urban 
development? Current status and outlook. Sustain. Cities Soc. 11, 31-39.

doi:10.1016/j.scs.2013.11.007

Sidiras, D.K., Koukios, E.G., 2004. Solar systems diffusion in local markets. Energy Policy 32, 20072018. doi:10.1016/S0301-4215(03)00173-3

Smith, A., Raven, R., 2012. What is protective space? Reconsidering niches in transitions to sustainability. Res. Policy 41, 1025-1036. doi:10.1016/j.respol.2011.12.012

Smith, A., Voß, J.-P., Grin, J., 2010. Innovation studies and sustainability transitions: the allure of the multi-level perspective and its challenges. Res. Policy 39, 435-448. doi:10.1016/j.respol.2010.01.023

Tyfield, D., Jin, J., 2010. Low-carbon disruptive innovation in China. J. Knowledge-Based Innov. China 2, 269-282. doi:10.1108/17561411011077909

Urban, F., Geall, S., 2014. Pathways Towards Renewable Energy in China: Prospects, Politics and Practices (No.70), STEPS Working Paper. Brighton.

Verbong, G.P.J., Geels, F.W., 2010. Exploring sustainability transitions in the electricity sector with socio-technical pathways. Technol. Forecast. Soc. Change 77, 1214-1221.

Wang, R.Z., Zhai, X.Q., 2010. Development of solar thermal technologies in China. Energy 35, 44074416. doi:10.1016/j.energy.2009.04.005

Weiss, W., Spörk-Dür, M., Mauthner, F., 2017. Solar Heat Worldwide: Global Market Development and Trends in 2016,Detailed Market Figures 2015. Gleisdorf.

Woersdorfer, J.S., Kaus, W., 2011. Will nonowners follow pioneer consumers in the adoption of solar thermal systems? Empirical evidence for northwestern Germany. Ecol. Econ. 70, 2282-2291. doi:10.1016/j.ecolecon.2011.04.005 
Yu, Z., Gibbs, D., 2018. Sustainability transitions and leapfrogging in latecomer cities: the development of solar thermal energy in Dezhou, China. Reg. Stud. 52,68-79. doi:10.1080/00343404.2016.1260706

Yuan, X., Zuo, J., 2011. Transition to low carbon energy policies in China-from the Five-Year Plan perspective. Energy Policy 39, 3855-3859. doi:10.1016/j.enpol.2011.04.017 